\title{
THE TUNDRA AND POLAR SEMI-DESERT LANDSCAPES OF BANKS ISLAND AND PRINCE PATRICK ISLAND, WESTERN CANADIAN ARCTIC
}

H.M. FRENCH ${ }^{1,2}$

\begin{abstract}
${ }^{1}$ Emeritus Professor, Departments of Geography and Earth Sciences,University of Ottawa, Canada. ${ }^{2}$ Adjunct Professor, Department of Geography, University of Victoria, Canada.
\end{abstract}

\begin{abstract}
Tundra and polar desert environments characterize the islands of the Western Canadian Arctic. Prince Patrick Island is a typical polar semi-desert; Banks Island illustrates the intermixing of polar-desert and tundra environments. Interpretation of these periglacial landscapes must consider not only the normal links that exist between rocks, relief, climate and weathering but also specific relationships between low temperature, aridity, snow, frozen ground, wind and vegetation.
\end{abstract}

Los paisajes de tundra y de semi-desierto polar de las islas Banks y Prince Patrick, Ártico Occidental Canadiense

RESUMEN. Los ambientes de tundra y polar desértico caracterizan a las islas del Ártico Occidental canadiense. La Isla de Prince Patrick es un semi-desierto polar típico; la isla de Banks ilustra la mezcla de ambientes de desierto polar y de tundra. La interpretación de estos paisajes periglaciares debe considerar no solo las relaciones existentes entre rocas, relieve, clima y meteorización, sino también relaciones específicas entre baja temperatura, aridez, nieve, suelo helado, viento y vegetación.

Key words: periglacial, tundra, polar desert, Banks Island, Prince Patrick Island, Western Canadian Arctic.

Palabras clave: periglaciar, tundra, desierto polar, Isla Banks, Isla Prince Patrick, Ártico Occidental Canadiense.

*Corresponding author: H.M. French. Departments of Geography and Earth Sciences, University of Ottawa, Canada. E-mail: hmfrench@shaw.ca 


\section{Introduction}

Periglacial environments are those in which cold, non-glacial processes dominate. Frost action and either seasonally or perennially-frozen ground (permafrost) are central characteristics (French, 2007). In the polar latitudes, periglacial environments range between polar desert, tundra, shrub tundra and boreal forest or taiga. In the montane environments of central Asia and Tibet, they range between steppe, steppe-tundra and semi-desert. The alpine environments of the mid-latitude mountains are a further type.

This paper describes the polar semi-desert and tundra environments that occur on two islands located between latitudes $72^{\circ}$ and $77^{\circ} \mathrm{N}$ in the Western Canadian Arctic (Fig. 1). Banks Island, the fourth largest in the Canadian Arctic, covers an area of $\sim 70,000 \mathrm{~km}^{2}$. Prince Patrick Island covers an area of $\sim 17,000 \mathrm{~km}^{2}$. Banks Island is separated from the mainland of Canada by Amundsen Gulf while M'Clure Strait separates Prince Patrick Island from Banks Island. These water bodies are ice-covered for more than 8-9 months of the year.

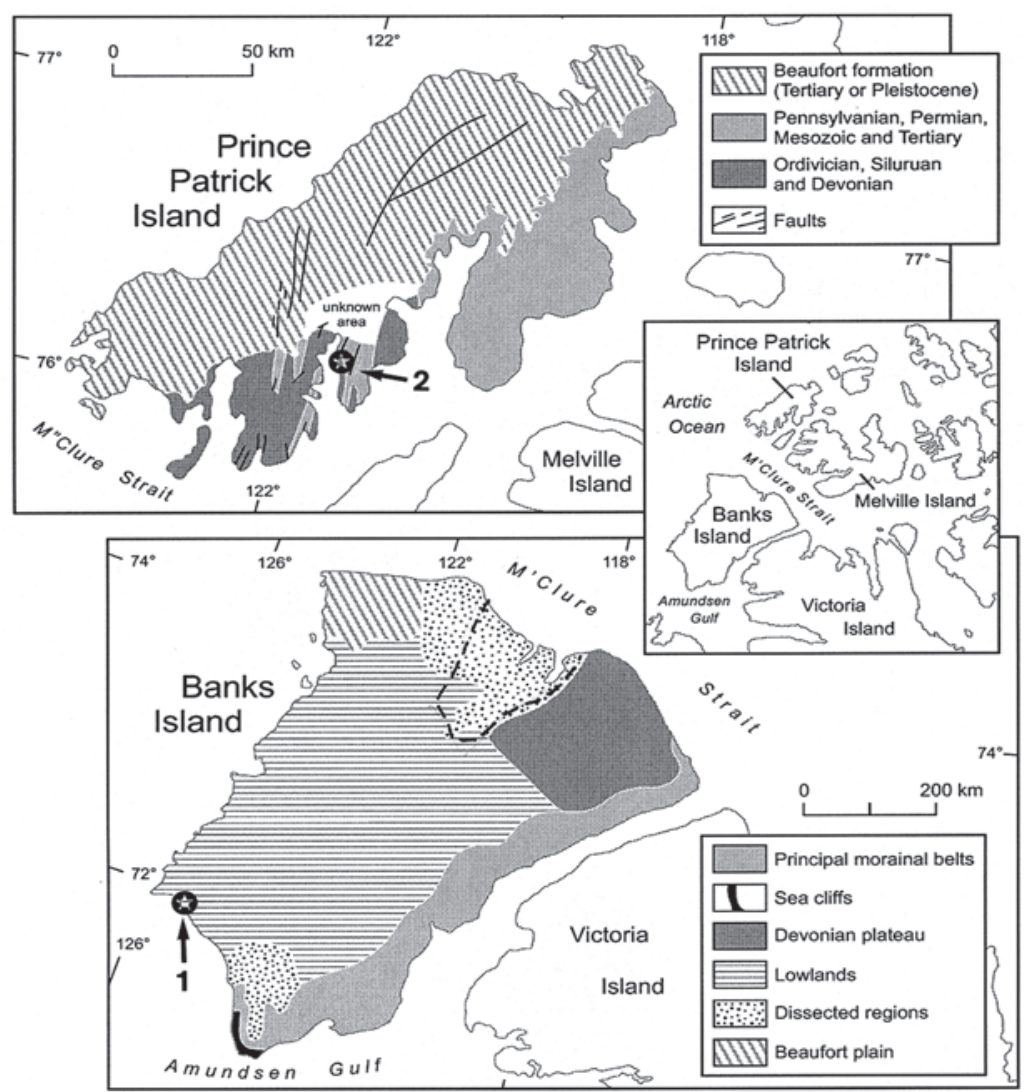

Figure 1. Location map of Banks Island and Prince Patrick Island, Western Canadian Arctic, showing the geology and major physiographic regions. Modified after Tozer and Thorsteinsson,

1962; Thorsteinsson and Tozer, 1964. The locations of Sachs Harbour and Mould Bay are indicated by arrows 1, 2, respectively. The approximate extent of Auklavik National Park on Banks Island is outlined by the dashed line. 


\section{Cold deserts}

Many periglacial environments, especially those in the high latitudes, are cold deserts. For example, in the climatic classification of Koeppen-Geiger, cold deserts are classified as either Bwk (areas that experience annual average temperatures less than $18^{\circ} \mathrm{C}$ ) or Dwc (areas that experience dry winters, less than 4 months above $10^{\circ} \mathrm{C}$ and the coldest month being lower than $-3^{\circ} \mathrm{C}$ ). While cold deserts are defined primarily on the basis of temperature, moisture availability is also a central concern. This is the balance between water supply, provided by precipitation ( $\mathrm{P}$, rain or snow), and water loss due to evapotranspiration $\left(\mathrm{PE}_{\mathrm{t}}\right.$, both evaporation from water and transpiration from plants and near-surface sediment). Thus, cold deserts can also be defined as to whether they are arid, hyper-arid, semi-arid or dry subhumid (Table 1).

Table 1. Classification of hot and cold deserts according to moisture variability and temperature regime (After Thomas, 2011).

A: Moisture availability:

\begin{tabular}{|l|c|c|c|}
\hline Classification & $\begin{array}{c}\text { Aridity Index } \\
\text { (A/I) range }\end{array}$ & $\begin{array}{c}\text { Precipitation } \\
\text { characteristics }\end{array}$ & $\begin{array}{c}\text { Precipitation } \\
\text { limits** }\end{array}$ \\
\hline Hyper-arid & $<0.05$ & $\begin{array}{c}12 \text { months without rain; } \\
\text { Interannual rainfall } \\
\text { variability } 100 \%\end{array}$ & $<25 \mathrm{~mm}$ year \\
\hline Arid & 0.05 to $<0.20$ & $\begin{array}{c}\text { Low and unreliable rainfall, } \\
50-100 \% \text { interannual } \\
\text { rainfall variability }\end{array}$ & $25-200$ mm year \\
\hline Semi-arid & 0.20 to $<0.50$ & $\begin{array}{c}\text { Seasonal rainfall; } 25-50 \% \\
\text { Interannual rainfall } \\
\text { variability }\end{array}$ & $200-500$ mm year \\
\hline Dry subhumid & 0.50 to $<0.65$ & $\begin{array}{c}\text { Reliable seasonal rainfall; } \\
25 \% \text { interannual rainfall } \\
\text { Variability }\end{array}$ & $500-1000$ mm year \\
\hline
\end{tabular}

* Aridity Index $(\mathrm{AI})=\mathrm{P} / \mathrm{PE}$, where $\mathrm{P}=$ annual precipitation and $\mathrm{PE}_{\mathrm{t}}=$ potential evaporation based upon Thornthwaite's 1948 Index of Moisture Availability ( $\mathrm{I}_{\mathrm{m}}$ ).

** For Banks Island and Prince Patrick Island, total precipitation (see Table 2) includes rain, snow, fog and freezing drizzle.

B. Temperature regime:

\begin{tabular}{|c|c|c|c|c|c|}
\hline \multicolumn{7}{|c|}{ Annual temperature regime } \\
\hline & Hot & Mild winter & Cool winter & Cold winter & Cold Desert* \\
\hline Coldest month ${ }^{\circ} \mathrm{C}$ & $10-30$ & $10-20$ & $0-10$ & $<10$ & $<-20 ?$ \\
\hline Warmest month ${ }^{\circ} \mathrm{C}$ & $>30$ & $10-30$ & $10-30$ & $10-30$ & $>10$ \\
\hline
\end{tabular}

*Cold deserts are arbitrarily defined as being areas where the warmest month $>10^{\circ} \mathrm{C}$ and the coldest month $<-20^{\circ} \mathrm{C}$. 
The aridity of cold deserts introduces complexity to periglacial landscape interpretation. First, low temperature not only reduces evaporation but also enhances sublimation and hence the direct removal of moisture (snow) to the atmosphere. A further complication is that a sparse vegetation cover reduces evapotranspiration losses while the presence of a frozen, largely impermeable substrate (permafrost) reduces infiltration into the ground. Both enhance the overall effectiveness of precipitation and surface runoff. Furthermore, the presence of snow, unevenly distributed across the landscape because of transport by wind in winter and persisting for many months in summer in certain localities, introduces spatial and temporal complexities to many landscape-forming processes.

Sometimes, the tundra is not regarded as a cold desert because many of the associated lowlands are well vegetated and wildlife is present. Large rivers drain the northern areas of the Eurasia and North American continents but this impression of moisture is deceptive because the discharge of these rivers is largely derived from mountainous regions that lie outside the tundra region. The reality is that most tundra regions experience no more than $\sim 200-500 \mathrm{~mm}$ of precipitation annually and, therefore, they fall within the semi-arid category (see Table 1A). A final consideration is that, at the higher northern latitudes, many tundra regions possess an intimate mix of poorlydrained but well-vegetated lowlands and well-drained but poorly-vegetated interfluves and uplands. This intermixing disguises the recognition of aridity.

The Banks Island tundra illustrates the difficulty of recognizing the tundra as a cold desert. Contrary to its climatic designation, the Banks Island tundra supports a highly productive ecosystem. This was the initial reason why mainland Inuit established a permanent settlement at Sachs Harbour in the late 1940s. While shallow interfluves and uplands are dominated by polar desert and semi-desert plant communities, broad river valleys and extensive lowlands support Arctic dwarf shrubs, grasses, sedges and flowering plants. These tundra meadows attract a diversity of flora and fauna. More than 15,000 muskoxen live in Auklavik National Park alone and total numbers on the island currently exceed 20-30,000, the highest density for this animal in the entire Canadian Arctic. Caribou, Arctic fox and wolf range widely, and numerous migratory birds such as geese are present during summer months. The larger lakes contain char and trout. Muskoxen meadows, the dens of foxes and the nesting or perching areas of predatory birds, such as owls and hawks, are often marked by tundra grasses and small mounds.

\section{Climate of the Western Arctic Islands}

Table 2 summarizes the annual temperature and precipitation regimes for Sachs Harbour, on the southwestern tip of Banks Island, and Mould Bay, on eastern Prince Patrick Island. The mean annual air temperatures are $-14^{\circ} \mathrm{C}$ and $-18^{\circ} \mathrm{C}$ respectively. Monthly average temperatures fall below $-30^{\circ} \mathrm{C}$ for several months during the winter and range between $1^{\circ} \mathrm{C}$ and $5^{\circ} \mathrm{C}$ during a short summer when the ground surface typically thaws to depths of between 0.5 and $1.0 \mathrm{~m}$. Beneath this seasonally-thawed layer (the active layer) the ground remains perennially frozen (permafrost) to depths that may exceed several hundreds of meters.

Table 2 indicates that the mean annual precipitation amounts for Sachs Harbour and Mould Bay total 114 and $81 \mathrm{~mm}$ respectively. It is clear that both islands fall within 
the 'arid' category (see Table 1). Between $40-50 \%$ of the annual precipitation on the two islands falls as rain during the 2-3 summer months. However, because of low temperatures, evaporative losses are relatively small, rain quickly percolates into the seasonally-thawed layer, and snow sublimates. The majority of precipitation falls as snow during the rest of the year. Wind redistributes the snow into either gullies or leeslope positions. Thus, during the winter months, the interfluves and higher elevations are largely bare of snow. This uneven spatial distribution allows not only frost to quickly penetrate snow-free surfaces in winter but also concentrates snowmelt runoff from large snow banks in a brief 2-3 week period during the spring.

Table 2. Average monthly temperature, precipitation data and frost statistics for Mould Bay (1948-1970, 15.2 m a.s.l.) and Sachs Harbour (1955-1970, 92.0 m a.s.l.). From Maxwell, 1980.

\begin{tabular}{|l|c|c|c|c|c|c|c|c|c|c|c|c|c|}
\hline TEMPERATURE $\left({ }^{\circ} \mathrm{C}\right)$ & $\mathrm{J}$ & $\mathrm{F}$ & $\mathrm{M}$ & $\mathrm{A}$ & $\mathrm{M}$ & $\mathrm{J}$ & $\mathrm{J}$ & $\mathrm{A}$ & $\mathrm{S}$ & $\mathrm{O}$ & $\mathrm{N}$ & $\mathrm{D}$ & Average \\
\hline $\begin{array}{l}\text { Mould Bay: } 76^{\circ} 15^{\prime} \mathrm{N} ; \\
133^{\circ} 2^{\prime} \mathrm{W} .\end{array}$ & -33.9 & -36.0 & -33.2 & -23.8 & -11.4 & -0.2 & +3.3. & +1.4 & -6.9 & -17.3 & -26.8 & -31.4 & -17.8 \\
\hline $\begin{array}{l}\text { Sachs Harbour: } \\
71^{\circ} 57^{\prime} \mathrm{N}, 124^{\circ} 44^{\prime} \mathrm{W} .\end{array}$ & -29.7 & -30.9 & -27.3 & -19.2 & -7.3 & +2.2 & +5.6 & +4.3 & -1.8 & -11.6 & -21.7 & -26.7 & -13.7. \\
\hline
\end{tabular}

\begin{tabular}{|l|c|c|c|c|c|c|c|c|c|c|c|c|c|}
\hline PRECIPITATION (mm) & J & F & M & A & M & J & J & A & S & O & N & D & Average \\
\hline Mould Bay: & 3 & 3 & 4 & 4 & 6 & 5 & 13 & 18 & 10 & 8 & 3 & 3 & 83 \\
\hline Sachs Harbour: & 3 & 4 & 4 & 3 & 9 & 10 & 16 & 21 & 16 & 16 & 7 & 5 & 114 \\
\hline
\end{tabular}

\begin{tabular}{|l|c|c|c|c|}
\hline FROST DATA & $\begin{array}{c}\text { Thawing-degree } \\
\text { days(TDD) }\end{array}$ & $\begin{array}{c}\text { Freezing-degree } \\
\text { days(FDD) }\end{array}$ & $\begin{array}{c}\text { Frost-free } \\
\text { period(days) }\end{array}$ & $\begin{array}{c}\text { Number of Freeze-thaw } \\
\text { cycles, annual average }\end{array}$ \\
\hline Mould Bay & $\sim 200$ & $\sim 7000$ & 23 & 13.4 \\
\hline Sachs Harbour & $\sim 400$ & $\sim 5500$ & 15 & 19.6 \\
\hline
\end{tabular}

\section{Glaciated terrain?}

It is generally agreed that Prince Patrick Island is located beyond the western limits of the NW Laurentide and Innuitian ice sheets (England et al., 2006, 2009). However, the presence of scattered erratics, meltwater channels and outwash fans suggest older, possibly local, ice caps on the central part of the island prior to the last cold period (Fyles, 1965).

The glacial history of Banks Island is more complicated. Based upon a widespread veneer of glacigenic and surficial materials, a complex sequence of Quaternary glaciations has been proposed (Vincent, 1982, 1983). The latest (Amundsen) advance of the Laurentide ice sheet reached the eastern part of the island and ice lobes extended westwards into Amundsen Gulf and M'Clure Strait. Under this scenario, the central lowlands remained ice-free during the Late Quaternary and only the extreme northwest (the Beaufort Plain) was unaffected by glaciation. A series of ice marginal drainage channels can be recognized (French, 1972a). More recent investigations (England et al., 2009; Lakeman and England, 2014) suggest that a thin and stationary (cold-based) ice sheet covered all of central and western Banks Island 
during the height of the last cold period. This is supported by the apparent absence of any faunal remains from central Banks Island that can be radiocarbon dated to the last major cold period ( 40-20ka). If this area were ice-free at that time, it would have acted as a refugium for both plants and animals. Yet only a single muskoxen bone, taken from a gravel bar of the Bernard River and dated at >34ka (Maher, 1968), has been found from this time period.

\section{Structure and relief}

In most regions of the world, the major landscape control is related to geology. This is certainly true for both Banks Island and Prince Patrick Island.

Banks Island contains a number of different physiographic regions (see Fig. 1). The northeast plateau consists of Devonian age limestone and the southern uplands consist of Precambrian gabbro rocks. These rocks form upland terrain rising to elevations of $\sim 700 \mathrm{~m}$. By contrast, the majority of the central and western lowlands are underlain by poorly consolidated Mesozoic-age sediments that vary in lithology from shale of the Christopher Formation to sands and gravels of the Eureka Sound and Beaufort Formations (Thorsteinsson and Tozer, 1962; Miall, 1979; Fyles, 1994). Fluvial dissection has resulted in relative relief that varies from less than $50 \mathrm{~m}$ to over $250 \mathrm{~m}$. The interfluves and upper slopes are covered with an extensive but thin veneer of till and glacio-fluvial deposits. Much of the lowland landscape consists of broad fluvial surfaces, probably formed by melt-water that flowed westwards away from the decaying Laurentide ice sheet to the east. The most deeply dissected terrain occurs in the central, north-central and southcentral parts of the island where relatively more cohesive shale and sandstone of the Christopher and Eureka Sound Formations are exposed in the valleys of the Thomsen, Kellett, Sachs and Masik Rivers. An extensive area of hummocky moraine mantles the eastern side of the island; this reflects the western edge of the Laurentide ice sheet.

On eastern Prince Patrick Island, outcrops of Paleozoic shale and sandstone produce structurally-controlled uplands subject to frost action and weathering. Here, the terrain is typically covered with a veneer of angular frost-shattered debris. On central and western Prince Patrick Island, desert-like terrain occurs on sediments composed of sands and gravels of the Beaufort Formation (Tozer and Thorsteinsson, 1964; Fyles, 1990). Undulating terrain with a relative relief of between 100 and $200 \mathrm{~m}$ is characterized by gentle slopes and shallow drainage channels that grade westwards towards the Arctic Ocean where they merge into broad alluvial surfaces, outwash fans and sandy plains. This terrain is devoid of striking landform features except for thermal-contraction-crack polygons.

\section{Permafrost, ground ice and water bodies}

Both islands are underlain by permafrost. Deep temperature measurements have been made at only one locality, the Storkerson Bay 1-15 exploratory well site located $\sim 110 \mathrm{~km}$ north of Sachs Harbour. There, the mean annual ground temperature at the depth of zero annual amplitude is $-13.1^{\circ} \mathrm{C}$ and permafrost thickness is approximately $250 \mathrm{~m}$ (Taylor and Judge, 1977). At Mould Bay, the similar temperature measurement is $\sim-14^{\circ} \mathrm{C}$. In all probability, maximum permafrost thicknesses exceed $300-500 \mathrm{~m}$ on both islands. Typically, maximum active-layer thicknesses on both islands vary between 50 and $75 \mathrm{~cm}$, depending upon local site conditions. 
In regions of continuous and thick permafrost, the presence of water bodies can result in unfrozen zones or taliks. This is certainly the case for Banks Island where numerous lakes and ponds exist and where large rivers, such as the Thomsen, Bernard and Big Rivers drain the central and western lowlands. On Prince Patrick Island, few water bodies or rivers are of sufficient size to induce the formation of taliks.

Ground ice is an important component of permafrost. On Banks Island, ground ice exposures are usually rare and short-lived. Gullies formed by fluvio-thermal erosion along the lines of ice wedges and undercut stream banks provide the best opportunities to observe ground-ice. Coastal exposures are useful (French and Harry, 1983) but rare because significant periods of open-water conditions are limited to the southwest corner of Banks Island. The presence of numerous thaw lakes (Harry and French, 1983) and the occurrence of man-induced thermokarst (French, 1975b, 1978) suggest that ground ice amounts are high. On Prince Patrick Island, knowledge of ground ice is limited.

\section{Snow, soil and vegetation}

Intense winter cold and an absence of sunlight for several months of the year inhibit plant growth. Thus, ecologists refer to the vegetated but treeless arctic as tundra. But where the vegetation is very sparse, the tundra progressively changes into polar semidesert or polar desert. Table 3 shows the vegetation zonation of the two islands in the context of the biogeographical zones and major vegetation types within the Eurasian and North American Arctic.

Table 3. The vegetation zonation of Banks Island and Prince Patrick Island and the main biogeographic zones and major vegetation types within the Russian and North American Arctic. Modified from Bliss, 1997.

\begin{tabular}{|c|c|c|c|c|c|c|}
\hline \multicolumn{7}{|c|}{ Russian Arctic } \\
\hline \multicolumn{5}{|c|}{ Tundra } & \multirow{2}{*}{\multicolumn{2}{|c|}{ Polar desert }} \\
\hline \multicolumn{3}{|c|}{ Sub-arctic Tundra } & \multicolumn{2}{|c|}{ Arctic Tundra } & & \\
\hline $\begin{array}{c}\text { Southern } \\
\text { variant }\end{array}$ & $\begin{array}{l}\text { Middle } \\
\text { variant } \\
\end{array}$ & $\begin{array}{c}\text { Northern } \\
\text { variant }\end{array}$ & $\begin{array}{c}\text { Southern } \\
\text { variant }\end{array}$ & $\begin{array}{c}\text { Northern } \\
\text { variant }\end{array}$ & $\begin{array}{c}\text { Southern } \\
\text { variant }\end{array}$ & $\begin{array}{c}\text { Northern } \\
\text { variant }\end{array}$ \\
\hline \multicolumn{7}{|c|}{ North American Arctic (Tedrow) } \\
\hline \multicolumn{4}{|c|}{ Low Arctic Tundra } & $\begin{array}{c}\text { Mid Arctic } \\
\text { Subpolar Desert }\end{array}$ & \multicolumn{2}{|c|}{$\begin{array}{l}\text { High Arctic } \\
\text { Polar Desert }\end{array}$} \\
\hline \multicolumn{7}{|c|}{ North America Arctic (Bliss) } \\
\hline \multicolumn{4}{|c|}{ Low Arctic } & \multicolumn{3}{|c|}{ High Arctic } \\
\hline \multicolumn{3}{|c|}{ Polar } & & & \multirow{2}{*}{\multicolumn{2}{|c|}{ Polar }} \\
\hline Semi-desert & & esert & Tundra & Tundra & & \\
\hline \multirow{2}{*}{$\begin{array}{l}\text { Tall shrub } \\
\text { tundra }\end{array}$} & \multirow{2}{*}{$\begin{array}{c}\text { Low shrub } \\
\text { tundra }\end{array}$} & \multirow{2}{*}{$\begin{array}{c}\text { Dwarf- } \\
\text { shrub- heath- } \\
\text { tundra }\end{array}$} & \multirow{2}{*}{$\begin{array}{l}\text { Dwarf- } \\
\text { shrub- heath- } \\
\text { tussock- } \\
\text { tundra }\end{array}$} & $\begin{array}{c}\text { Graminoid- moss } \\
\text { tundra }\end{array}$ & $\begin{array}{l}\text { Cushion- plant- } \\
\text { cryptogam }\end{array}$ & $\begin{array}{l}\text { Herb- } \\
\text { cryptogam }\end{array}$ \\
\hline & & & & Low shrub tundra & Cryptogam- herb & \\
\hline $\begin{array}{l}\text { Graminoid- } \\
\text { moss tundra }\end{array}$ & $\begin{array}{r}\text { Cushic } \\
\text { cryptoge }\end{array}$ & $\begin{array}{l}\text { on-plant } \\
\text { am tundra }\end{array}$ & & & & \\
\hline \multicolumn{7}{|l|}{ This paper } \\
\hline & & & \multicolumn{3}{|c|}{ BANKS ISLAND } & \\
\hline & & & & \multicolumn{3}{|c|}{ PRINCE PATRICK ISLAND } \\
\hline
\end{tabular}


Botanists were the first to draw attention to the close relationship that exists between vegetation, snow and wind in the Western Canadian arctic (Porsild, 1955, 60-67; Porsild, 1957, 5-7) (Fig. 2). So-called 'snowbed' habitats are favoured localities for vegetation growth. They also enhance the activity of mass-wasting processes. Snow (moisture) is also the pivotal variable in the formation of 'patchy wetlands' (Woo and Young, 2003). Other favoured habitats for vegetation growth are gullies, poorly-drained valley bottoms and low-level fluvial terraces.
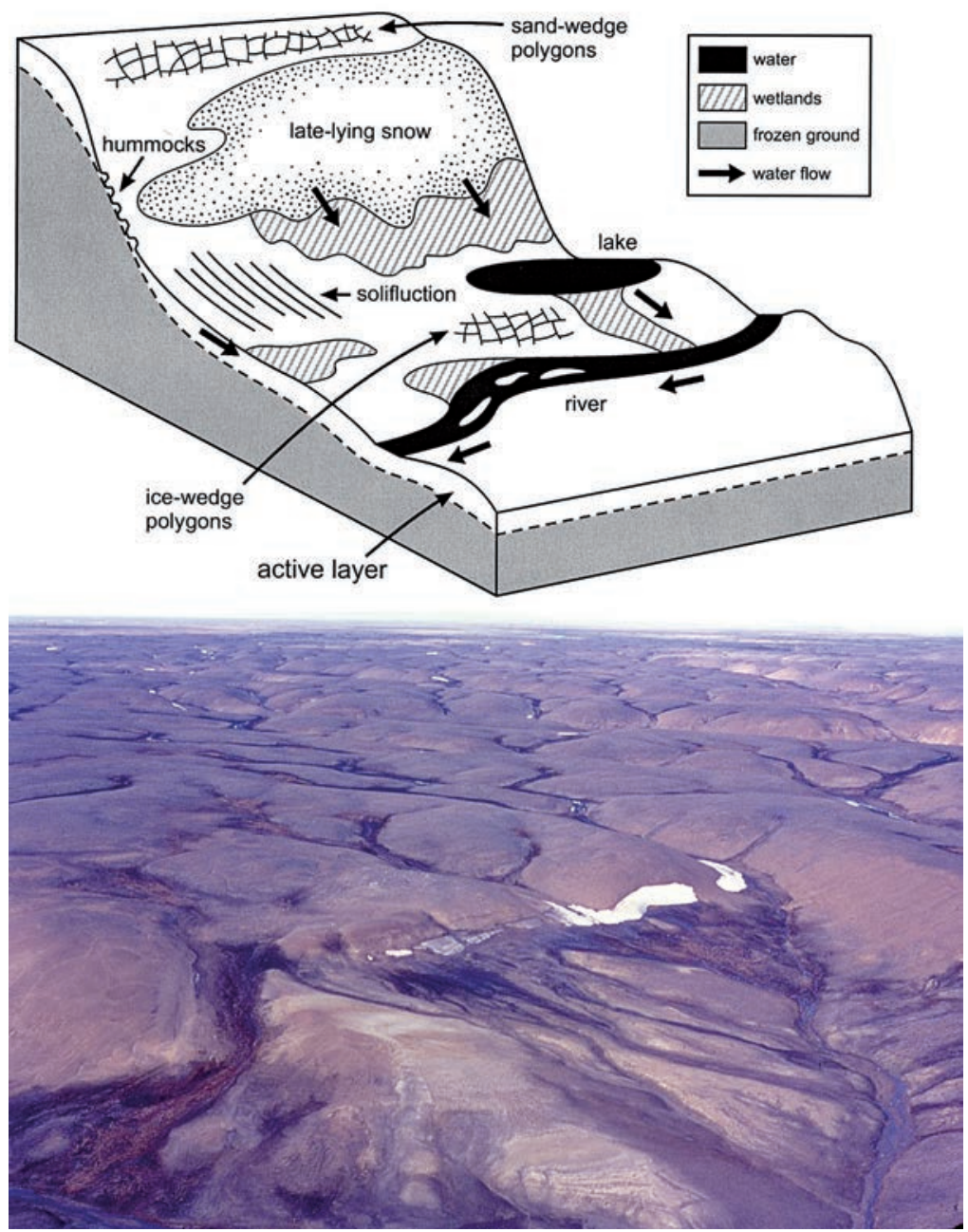

Figure 2. Snow and vegetation relationships in the polar semi-desert landscape: Upper: model of the occurrence of 'snowbed' or 'patchy wetland' sites in the Canadian high Arctic. Lower: the photo shows typical polar semi-desert terrain on western Prince Patrick Island where tundra vegetation is restricted to patchy wetland sites. The photo also illustrates the fluvial dissection of the landscape of western Prince Patrick Island. The figure is modified after Woo and Young,

2003. The photo is by H. M. French. 
The mixing of the tundra and polar desert landscapes is largely controlled by topography, parent material and drainage. For example, Figure 3 illustrates how the more sandy the parent material is, the greater is the percentage of the High Arctic landscape that is polar desert. The transition is through so-called 'soils of the hummocky ground' or 'soils of the polar desert-tundra interjacence' (Tedrow, 1974). Saline and alkaline soil conditions are characteristic of the transition and of the polar desert terrain; typically, salt crusts and efflorescence form after several days of rainfree, windy conditions (Tedrow, 1966) and carbonates may be precipitated on the lower sides of rock fragments.

The lowlands of central and western Banks Island are a classic illustration of the intermixing of the tundra and polar semi-desert landscapes. Areas of closed vegetation constitutes anywhere between 60 and $90 \%$ of the island landscape. Although woody shrubs occur in sheltered localities, trees are absent. The progressive transition from bog and sedge-moss tundra in the lowlands to cushion plant-lichen communities on the uplands is usually accomplished by a gentle slope upon which earth hummocks are widespread (Tedrow and Douglas, 1964). A similar but more abrupt transition occurs on Prince Patrick Island (Tedrow et al., 1968) where the vegetation cover is often less than $10 \%$ and areas of wellvegetated tundra are restricted to depressions and areas adjacent to drainage channels. Typically, the polar desert vegetation shows little variation from place to place and the plants are small, close to the ground and often widely separated with bare soil or rock in between. There is a progressive change from lowland terrain dominated by cryptogam-herb and moss graminoid tundra to simple herb barrens on the uplands. The extreme growth environments are (a) late-lying snow banks where the growing season is extremely short and (b) windswept dry ridges and interfluves. Here, plants tend to be either cryptogams (mosses in snowbed sites) or crustose lichens on ridges and summits.

\section{The role of wind}

The direct role of wind in fashioning the landscapes of the two islands is relatively small (Pissart, 1966; French, 1972b). This opinion is at variance with the traditional importance attached to wind by the early explorers of Polar Regions. It should be noted that many of these early accounts are from areas adjacent to either large ice sheets or high mountains, or both, such as Antarctica and northern Greenland, where strong katabatic winds are common. Neither Banks Island nor Prince Patrick Island is located in close proximity to either large ice sheets and/or high mountains. Thus, the magnitudes and consistencies of wind direction, speed and duration are unremarkable (Table 4). 

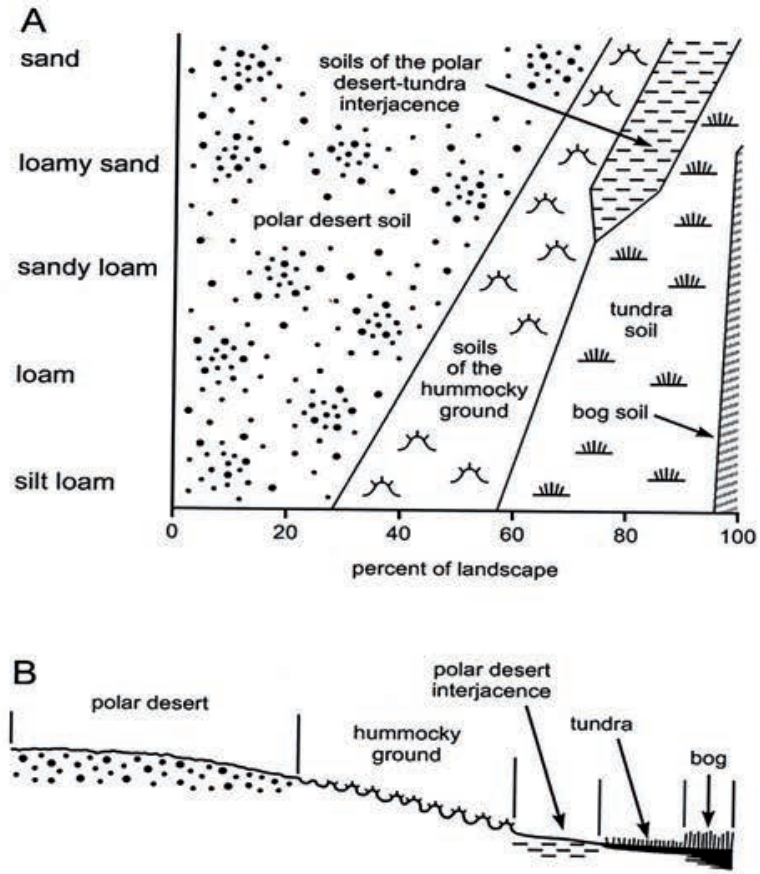

C

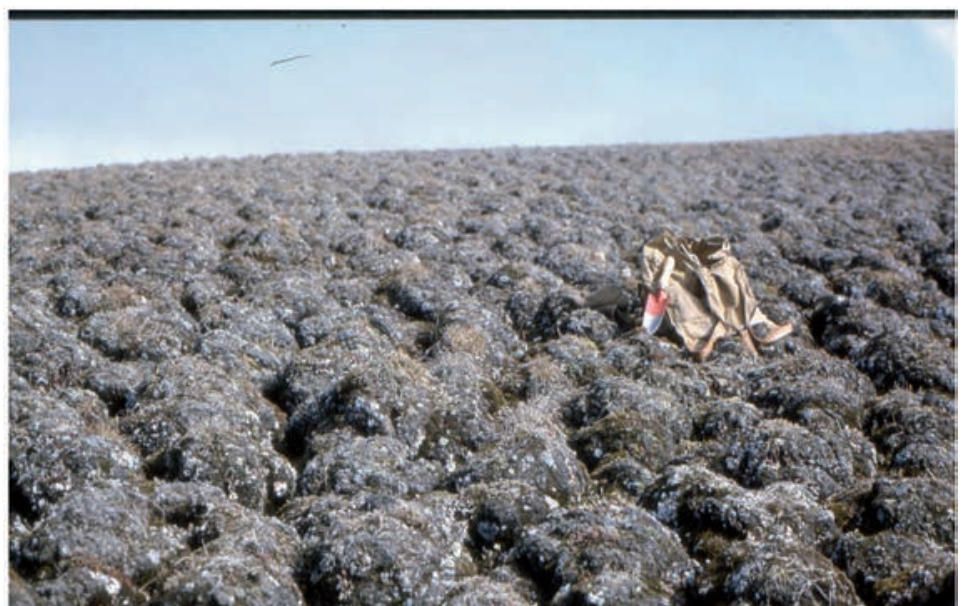

Figure 3. The typical soil transition between tundra and polar desert landscapes: (A) - a diagrammatic plot showing that the sandier the parent material the greater is the percentage of polar desert; $(B)$ - a sketch showing how the transition from tundra to polar desert terrain depends upon relief, parent material and moisture conditions. Diagrams A and B are modified after Tedrow, 1974. The photo $(C)$ shows the typical slope hummocks on northern Banks Island that characterize the terrain transition from wet tundra in lowlands to polar semi-desert conditions on upper slopes and interfluves. The photo is by H. M. French. 
Table 4. Wind speed $(\mathrm{km} / \mathrm{hr}$ ) and duration (values of hourly wind speed $(\mathrm{km} / \mathrm{hr}$ ) equalled or exceeded at a given probability level), Mould Bay, 1953-1972, Sachs Harbour, 1955-1972. From Maxwell, 1980.

\begin{tabular}{|c|c|c|c|c|c|c|c|c|}
\hline \multicolumn{9}{|c|}{ Percentage probability* } \\
\hline & 1 & 5 & 10 & 20 & 50 & 70 & 90 & 98 \\
\hline \multicolumn{9}{|l|}{ Mould Bay } \\
\hline Dec-Jan-Feb & 61 & 44 & 34 & 24 & 10 & 2 & - & - \\
\hline Mar-Apr-May & 50 & 35 & 29 & 23 & 10 & 3 & - & - \\
\hline Jun-Jul- Aug & 50 & 37 & 31 & 24 & 15 & 10 & 3 & - \\
\hline Sept-Oct-Nov & 52 & 39 & 32 & 24 & 13 & 5 & 1 & - \\
\hline \multicolumn{9}{|c|}{ Sachs Harbour } \\
\hline Dec-Jan-Feb & 56 & 37 & 31 & 24 & 15 & 10 & 5 & 2 \\
\hline Mar-Apr-May & 52 & 39 & 34 & 27 & 16 & 11 & 6 & 2 \\
\hline Jun- Jul- Aug & 47 & 35 & 31 & 26 & 18 & 13 & 6 & 2 \\
\hline Sept-Oct-Nov & 44 & 35 & 32 & 29 & 18 & 13 & 8 & 2 \\
\hline
\end{tabular}

*For example, during the December-February perial, there is a 5\% probability of an hourly wind speed of $44 \mathrm{~km} / \mathrm{hr}$ being equalled or exceeded.

It follows that corrasion by blowing ice crystals, often cited as the important wind-abrading agent in high latitudes, is relatively unimportant. Although winter temperatures drop below $-25^{\circ} \mathrm{C}$ to $-30^{\circ} \mathrm{C}$ for several months each year on the islands and a Mohs hardness of 3-4 might reasonably be expected for blowing ice crystals, monthly wind speeds during that period are less than $20 \mathrm{~km} / \mathrm{hr}$. Furthermore, in the coldest period of the year (December-February), there is only a 5\% probability of hourly wind speed in excess of $37-44 \mathrm{~km} / \mathrm{h}$ (see Table 4 ). This probably explains why windfacetted pebbles are not found. In fact, the main geomorphic effect of the wind is to (1) remove fine particles from bare surfaces and interfluves during winter, (2) encourage the formation of saline and alkaline soil through the rise of capillary moisture, and (3) redistribute snow and wind-blown sediment to gullies and valley bottoms where these sediments form localised niveo-aeolian deposits in spring as the snow ablates (Pissart, 1966). Additionally, on Banks Island, many bare alluvial surfaces within the larger river valleys experience local, thermally-induced, winds in summer ('dust devils') that cause deflation and cover-sand deposition (Pissart et al., 1977).

The indirect effects of wind are more subtle and most obvious on Banks Island where the northwest and southwest corners experience consistent southwesterly winds coming from the southern Beaufort Sea. The preferential accumulation of snow on the lee (east-facing) slopes results is the asymmetry of stream valleys in the extreme northwest (French, 1970, 1971a) while the formation of oriented (D-shaped) thaw lakes in the Sachs River lowlands of southwest Banks Island is thought to be related to the dominant wind directions(s) (Harry and French, 1983). 


\section{Landscape features}

Some of the typical periglacial landforms of Banks Island and Prince Patrick Island are illustrated in Figs. 4, 5 and 6. They can be summarized under three broad headings:
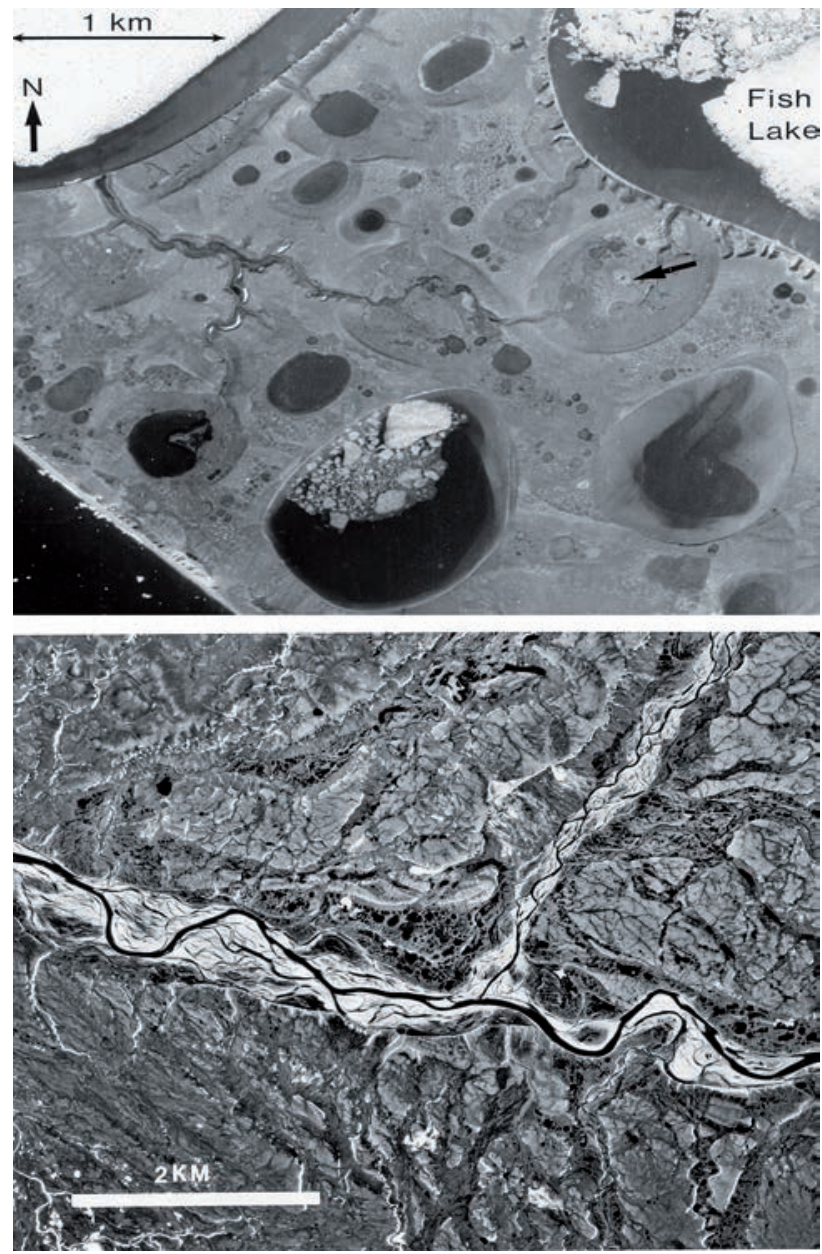

Figure 4. Vertical air photographs of parts of the Banks Island tundra:

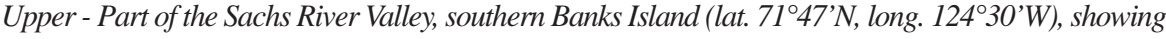
tundra terrain with ice-wedge polygons, D-shaped thermokarst lakes, drained thaw-lake basins and numerous tundra ponds. Gully erosion (stream tapping) along ice-wedge systems has caused the draining of adjacent thermokarst lakes. The arrow indicates a small closed-system pingo that has grown in one of the drained-lake basins. National Air Photo Library, Natural Resources Canada, Ottawa, print A-15980-25. Lower - Part of the Bernard River Valley, central Banks Island (lat, $73^{\circ} 45^{\prime} \mathrm{N}$, long. $122^{\circ} 15^{\prime} \mathrm{W}$ ). The main channel of the Bernard River is sinuous and the braided channel floor is flanked by an alluvial floodplain and several low terraces containing numerous tundra ponds and small thermokarst lakes. The current Bernard River drainage is misfit. The surrounding upland terrain represents former outwash surfaces and melt-water channels that are now being modified by fluvial dissection and mass-wasting processes.

National Air Photo Library, Natural Resources Canada, Ottawa, print A-17564-48. 

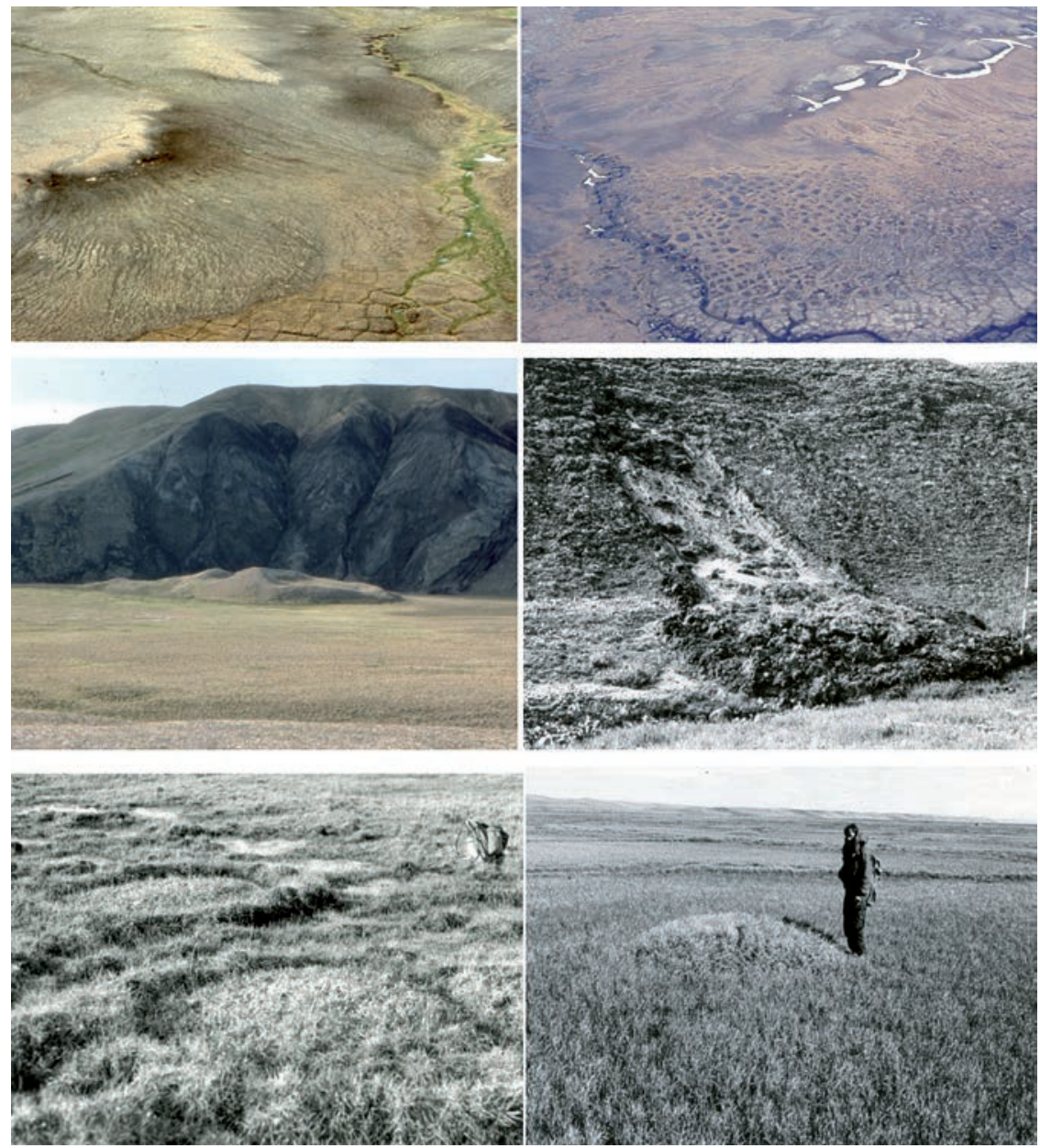

Figure 5. Geomorphic features of the Banks Island tundra: Upper left - Terrain underlain by fluvioglacial outwash and/or sands and gravels of the Beaufort and Eureka Sound Formations favours slopewash and mass-wasting processes that result in gentle slopes and broad interfluves. Location Thomsen River lowlands, north-central Banks Island, July 1977 (see Lewkowicz, 1983). Upper right - High- and low-centred ice-wedge polygons, 10-15 in dimensions, are widespread on poorly-drained lower slopes and terraces. Fluvial erosion operates preferentially along the lines of the ice-wedges. Late-lying snow-banks occupy lee-slope positions. Location - south-central Banks Island, July 1975. Middle left - A partially-collapsed closed-system pingo, $7.5 \mathrm{~m}$ high, in a valley eroded within shale of the Christopher Formation. Location - Sachs River catchment, southern Banks Island, August 1975 (see French and Dutkiewicz, 1976). Middle right - Slopes developed in shale of the Christopher Formation experience shallow failure in the active layer, as shown here, or skin flows ('active layer detachment failures'). These commonly occur in years of rapid summer thaw and/or after periods of summer rain. Location - Masik River Valley, southern Banks Island, August 1969. Lower left - Non-sorted circles with tussock grass borders are common on silty poorly-drained sites. Location, east-central Banks Island, July 1973. Lower right. - An ice-cored mound (hydrolaccolith) has formed in the centre of poorly-drained low-centered ice-wedge polygon terrain. Location - Masik River Valley, southern Banks Island, August 1969 (see French, 1971b). All photos are by H. M. French. 

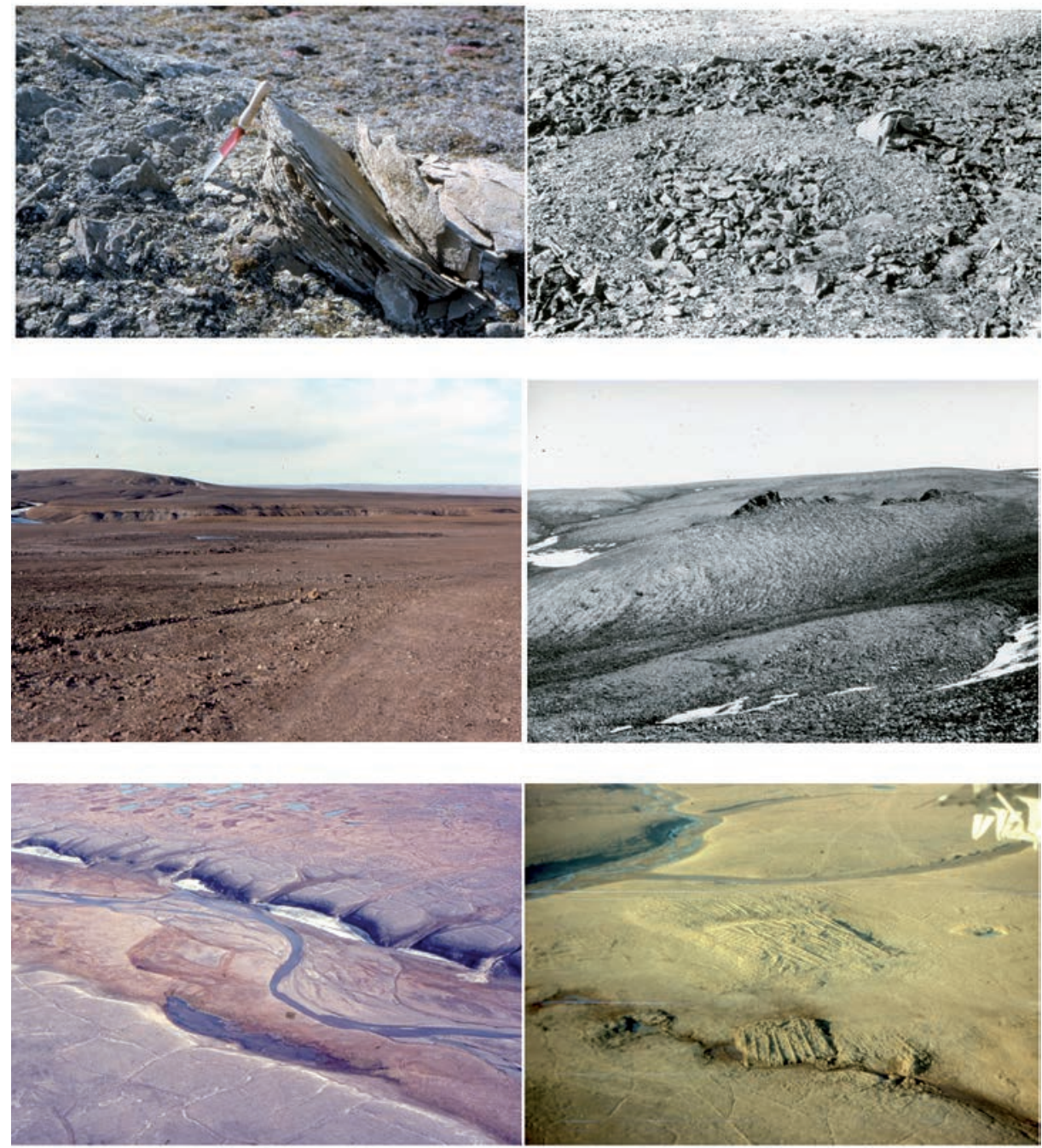

Figure 6. Geomorphic features of the polar semi-desert landscape of Prince Patrick Island: Upper left - A poorly-lithified Mesozoic-age sandstone boulder has been subject to frost action, near Mould Bay, June 1968. Upper right - An unusual frost-induced non-sorted circle formed in angular sandstone-derived regolith, near Mould Bay, June 1968. Middle left - Typical bedrock terrain near Wilkie Point, eastern Prince Patrick Island, is largely devoid of vegetation. A wind-deflated gravel veneer covers the surface. August 1976. Middle right - Hillslope tors occur on well-bedded sandstone with mass-wasting on surrounding slopes, near Mould Bay, late June 1968. Lower left - Box-shaped valley with braided stream channel, now partially dry, early July 1968, eastern Prince Patrick Island. Large sand-wedge polygons are visible on the low terrace in bottom left corner. Lower right - Oblique air view of the Elf Oil Ltd Dyer Bay I-59 exploratory well site located on sandy alluvial outwash plain, southern Prince Patrick Island. The well was drilled in the 1974-1975 winter. The photo was taken in August 1976 (see French, 1978). The lack of terrain disturbance around the site reflects the absence of vegetation and minimal ground ice. All photos by H. M. French. 


\subsection{Rivers and valleys}

The lowland tundra of Banks Island is one of gentle hills and broad valleys currently drained by snowmelt-derived waters. The majority of rivers, such as the Bernard, Storkerson, Big and Kellett Rivers, flow northwestwards towards the Beaufort Sea. Discharge is concentrated during a few weeks in late spring. Braided steam channels are typical and reflect a combination of the predominantly nival discharge and the high sediment load derived from the weakly consolidated sands and gravels that underlie the central lowlands. The exception is the Thomsen River, the longest on the island that flows northwards for much of its length in a single channel to exit in Castel Bay and M'Clure Strait. The lack of braiding is best explained by the low sediment load resulting from the cohesive nature of the shale bedrock that underlies much of this catchment.

The drainage is clearly misfit because extensive low fluvial terraces occur in most valleys, and large palaeo-outwash surfaces and abandoned meltwater channels can be recognized. If the central and western lowlands had been ice-free during the Late Wisconsin, as suggested by Vincent $(1982 ; 1983)$, the drainage pattern can be interpreted to reflect meltwater drainage from the ablating Late Wisconsinan ice sheet to the east. But if a cold-based ice cover had been present, as suggested by England et al. (2009) and Lakeman and England (2014), the drainage may reflect the in-situ disintegration of this ice cover. Anomalous drainage patterns and the seemingly random occurrence of glacigenic sediments, kame-like features and scattered erratics over the central lowlands support this interpretation. Only the simple dendritic drainage pattern of the never-glaciated Beaufort Plain, consisting of a series of northwestward-flowing streams with a striking asymmetry of valley side slopes, appears to reflect a quasi geomorphic equilibrium.

The polar semi-desert landscape of Prince Patrick Island also gives the appearance of a fluvially-fashioned landscape. Braided streams within shallow box-shaped channels are typical. During winter, the stream channels are filled with wind-blown snow while upland surface are blown clear of snow; snowmelt in spring is rapid and by early summer most stream channels are largely dry (Pissart, 1967b). In the western lowlands broad alluvial surfaces have been formed by the coalescing of large braided stream channels. Evidence of larger discharges in the past is given by extensive outwash fans and broad fluvial channels that are probably associated with the decay of local ice caps on the higher elevations.

\subsection{Frost action, mass wasting and patterned ground}

Direct frost action, in the form of mechanical weathering, is more obvious on uplands underlain by coherent Paleozoic and Mesozoic age bedrock than on lowlands developed upon unconsolidated sands, silts and gravels. For example, outcrops of Paleozoic shale and sandstone on the eastern side of Prince Patrick Island produce structurallycontrolled uplands subject to frost action and weathering. Here, the ground surface is typically covered with a veneer of angular frost-shattered debris. Although frost wedging (ice segregation) is known to be an effective mechanism for rock disintegration, others, 
such as either thermal stress or 'explosive shattering', may be equally important in this arid, polar desert environment. In areas of silty regolith, and where sufficient moisture is present, annual freezing and thawing can lead to the formation of sorted and non-sorted circles But, in general, the polar semi-desert terrain of Prince Patrick Island lacks the widespread development of the patterned ground features that characterise more humid cold environments.

On the poorly-drained tundra lowlands of Banks Island, the most common form of patterned ground is the non-sorted circle, or mudboil. On the gentle upper slopes, solifluction and slopewash processes are widespread, especially at and below snow-bank sites. Rates of solifluction movement range from between 0.5 and $2.0 \mathrm{~cm} / \mathrm{yr}$ (French, 1974a; Egginton and French, 1985). By moving material from higher to lower elevations solifluction forms sheets and lobes and contributes to a general flattening of the landscape. Erosion by overland flow is also widespread, especially at and below snow-bank sites. For example, estimates of erosion via suspended sediment in north-central Banks Island suggest between 1 and $5 \mathrm{~mm} / 1000$ years is normal but this probably increases to between 10 to $50 \mathrm{~mm} / 1000$ years in bare areas more characteristic of the polar desert (Lewkowicz, 1983; Lewkowicz and Kokelj, 2002). Where concentrated on low-angled slopes, surface flow erodes shallow linear depressions colonized by vascular plants (Salix sp., Dryas sp.); this results in nonsorted stripes, $0.5-1.0 \mathrm{~m}$ in width. Rapid mass movements, such as active-layer-detachment failures, are restricted to areas where shale of the Christopher Formation outcrops. These occur usually when summer rain has led to prior saturation of the overlying active layer. The high ice content at the active layer-permafrost interface accentuates and promotes slippage. Retrogressive thaw slumping, where headwall retreat may average several metres a year, is widespread on the hummocky morainal terrain of eastern Banks Island (French and Egginton, 1973; French, 1974b); these slumps are usually initiated when buried glacier ice bodies become exposed by fluvial erosion.

\subsection{Permafrost-related features}

On Banks Island, extensive and poorly-drained river terraces and floodplains are characterised by thermal-contraction-crack polygons. Some are depressed centre (so-called 'fortress', or thermokarst) polygons and most are underlain by epigenetic ice wedges. However, exposures of the wedge ice are rare. Typically, exposures are caused by fluvio-thermal erosion that operates preferentially along the ice wedges in the early spring. On sloping terrain, the upper slopes probably contain anti-syngenetic wedges, as described by Mackay (1995).

Ground ice amounts on the Banks Island tundra can only be approximated. Judging by conditions in the Sachs River lowlands, ice may constitute $~ 50-55 \%$ of the upper $8.0 \mathrm{~m}$ of permafrost (French and Harry, 1983). Almost certainly, this explains the numerous thermokarst lakes and ponds that cover the tundra; most are small, less than 200-300 m in diameter and generally shallow, less than 2.0-3.0 m deep. The majority do not show any preferential orientation, the only exception being the preferred $\mathrm{D}$-shaped thaw lakes of the Sachs River lowlands. A few of the larger lakes on the island are not thermokarstic in origin; these do not freeze to their bottom in winter and are well known to residents of Sachs Harbour because they usually contain arctic char and trout. 
Frost mounds on the Banks Island tundra are neither as large nor as numerous as those in the well-known Mackenzie Delta region. At least 15-20 closed-system (hydrostatic) pingos have been recognized; most are small and partially collapsed, some form elongate esker-like ridges and few, if any, are actively growing. The vast majority are located on fluvial terraces and abandoned river channels within the major valleys. All these features probably formed following freezing of sub-river taliks that must have existed beneath the deeper portions of rivers when discharges were higher than today (Pissart and French, 1976; French and Dutkiewicz, 1976). Radiocarbon dates suggest pingo growth on Banks Island occurred between $\sim 5.0 \mathrm{ka}$ and $\sim 2.5 \mathrm{ka}$ (see French et al., 1982, Table 1). The remnants of seasonal frost mounds can also be seen on many river terraces (French, 1975a, 1976) and the active formation of icing blisters can be observed today in winter on current floodplains (e.g. see French, 2007).

The range of permafrost-related landforms on Prince Patrick Island is far more limited. This must reflect the generally lower ground-ice amounts. In the absence of reliable field data, one must assume that ice volumes within the upper 5-10 $\mathrm{m}$ are as little as 10-15\%. This assumption is supported by the minimal levels of terrain disturbance that occurred during the drilling of exploratory oil wells in the 1970s at a number of polar semi-desert sites on Prince Patrick (French, 1978, 21-22). For example, on Prince Patrick Island, the Elf Dyer Bay I-59 well was located on a sandy gravelly outwash surface underlain by sand and gravel of the Beaufort Formation. Drilling and site restoration were completed without significant environmental or terrain problems. A similar situation occurred at the Elfex et al Ltd Wilkie Point J-51 well, located on terrain underlain by sandstone of the Wilkie Point Formation. Both sites illustrate the barren and inhospitable nature of much of the polar semi-desert landscape of Prince Patrick Island.

Thermal-contraction-crack polygons, $10-20 \mathrm{~m}$ in size, characterize the western and central parts of the island. Limited field observations indicate that wedges of sand and gravel, and not wedges of ice, underlie the polygons (Pissart, 1968). They appear similar to the sandwedge polygons described from Antarctica (Péwé, 1959). However, smaller polygons, 2-4 m in dimensions, occur in shale bedrock near Mould Bay and may be the result of desiccation. Thaw lakes, thermokarst phenomena, and other visible signs of ground ice are largely lacking on Prince Patrick Island. An exception is the presence of a number of partially-collapsed and elongate pingo-like forms (Pissart, 1967a). Many appear similar to those on Banks Island (see above). Some are especially problematic and appear related to deep-seated faults in the underlying Palaeozoic rocks (see Fig. 1). One suggestion is that these are ancient pingos, or ice hydrolaccoliths, formed by water movement along these faults (Pissart and French, 1974). Their precise age and origin is problematic.

\section{Conclusions}

The periglacial landscapes of Banks Island and Prince Patrick Island reflect both structural control and the cold, arid climate currently experienced. Technically, both islands are cold deserts. Although the Quaternary glacial history of this part of the Western Canadian Arctic is still not fully understood, it must be assumed that the majority of terrain on both islands has experienced cold non-glacial (periglacial) conditions 
for much of the Quaternary. As such, their landscapes must be regarded as being in quasi-equilibrium. However, geomorphic investigations are relatively few, especially on Prince Patrick Island, and further studies are required. Landscape observations need to be interpreted within the context of the intimate relationships that exist between low temperature, aridity, snow, frozen ground, wind and vegetation.

\section{Acknowledgements}

This paper is in memory of my late colleague and friend, Professor Albert Pissart, who died in 2014. His fieldwork on Prince Patrick Island in 1965 and 1966, our joint fieldwork on Banks Island in 1974 and his constant advice and support in subsequent years provided me with much insight and stimulation.

Field work conducted on Banks Island between 1968 and 1985 and on Prince Patrick Island in 1968 and 1976 was supported by numerous agencies and organizations; these included The Geological Survey of Canada (GSC), the Natural Sciences and Engineering Research Council (NSERC), The Polar Continental Shelf Project (PCSP), Environment Canada, Indian and Northern Affairs Canada, University of Ottawa, Elf Aquitaine, Panarctic Oils, and the Arctic Petroleum Operators Association (APOA).

\section{References}

Bliss, L.C. 1997. Arctic ecosystems of North America. In F.E. Wielgolaski (ed.), Ecosystems of the World 3, Polar and Alpine tundra, Elsevier, pp. 551-683.

Egginton, P.A., French, H.M. 1985. Solifluction and related processes, Eastern Banks Island, NWT, Canadian Journal of Earth Sciences 22, 1671-1678.

England, J.H., Furze, M.F.A., Doupe, J.P. 2009. Revision of the NW Laurentide ice Sheet: implications for paleoclimate, the northeast extremity of Beringia, and Arctic Ocean sedimentation. Quaternary Science Reviews 28, 1573-1596.

French, H.M. 1970. Soil temperatures in the active layer, Beaufort Plain. Arctic 23, 229-239.

French, H.M. 1971a. Slope asymmetry of the Beaufort Plain, northwest Banks Island, NWT, Canada. Canadian Journal of Earth Sciences 8, 717-731.

French, H.M. 1971b. Ice-cored mounds and patterned ground, Southern Banks Island, Western Canadian Arctic. Geografiska Annaler 53A, 32-38.

French, H.M. 1972a. Proglacial drainage of northwest Banks Island, District of Franklin, NWT. The Muskox, 10, 26-31.

French, H.M. 1972b. The role of wind in periglacial environments, with special reference to northwest Banks Island, Western Canadian Arctic. In W.P. Adams, F. Helleiner (eds.), International Geography, 1972, Volume 1, University of Toronto Press, pp. 82-84.

French, H.M. 1974a. Mass wasting at Sachs Harbour, Banks Island, NWT, Canada. Arctic and Alpine Research 6, 71-78.

French, H.M. 1974b. Active thermokarst processes, Eastern Banks Island, Western Canadian Arctic. Canadian Journal of Earth Sciences 11, 785-794.

French, H.M. 1975a. Pingo investigations and terrain disturbance studies, Banks Island, District of Franklin. Geological Survey of Canada Paper 75-1, 259-264.

French, H.M. 1975b. Man-induced thermokarst, Sachs Harbour airstrip, NWT, Canada. Canadian Journal of Earth Sciences 12, 132-144. 
French, H.M. 1976. Pingo investigations, Banks Island, District of Franklin. Geological Survey of Canada Paper 76-1, 235-238.

French, H.M. 1978. Sump Studies 1; Terrain disturbances. Environmental Studies 6, Department of Indian Affairs and Northern Development, Ottawa, $52 \mathrm{pp}$.

French, H.M. 2007. The Periglacial Environment. Third Edition. Wiley, Chichester, 458 pp.

French, H.M., Dutkiewicz, L. 1976. Pingos and pingo-like forms, Banks Island, Canada. Biuletyn Peryglacjalny 26, 211-222.

French, H.M., Egginton, P.A. 1973. Thermokarst development, Banks Island, Western Canadian Arctic. In Permafrost: North American Contribution, $2^{\text {nd }}$ International Conference on Permafrost, Yakutsk, USSR. National Academy of Sciences Publication 2115, Washington D.C., pp. 203-212.

French, H.M., Harry, D.G. 1983. Ground-ice conditions and thaw lake evolution, Sachs River lowlands, Banks Island, Canada. In H. Poser and E. Schunke (eds.), Mesoformen des reliefs in heutigen Periglazialraumes, Abhandlungen der Akademie der Wissenschaften in Gottingen 35, Vandenhoeck \& Ruprecht, Göttingen, pp. 70-81.

French, H.M., Harry, D.G., Clark, M.J. 1982. Ground ice stratigraphy and Late Quaternary events, southwest Banks Island, Canadian Arctic. In H.M. French (ed.), The Roger J. E. Brown Memorial Volume: Proceedings of the Fourth Canadian Permafrost Conference, National Research Council of Canada, Ottawa, pp. 81-90.

Fyles, J.G. 1965. Surficial geology, Western Queen Elizabeth islands. Geological Survey of Canada Paper 65-1, 3-5.

Fyles, J.G. 1990. Beaufort Formation (Late Tertiary) as seen from Prince Patrick Island, Arctic Canada. Arctic 43, 393-403.

Fyles, J.G., Hills, L.V., Matthews, J.V. Jr., Barendregt, R., Baker, J., Irving E., Jette, H. 1994. Ballast Brook and Beaufort Formation (Late Tertiary) on Northern Banks Island, Arctic Canada. Quaternary International 22/23, 141-171.

Harry, D.G., French, H.M. 1983. The orientation of thaw lakes, southwest Banks Island, Arctic Canada. In Proceedings, Fourth International Conference on Permafrost. National Academy Press, Washington DC, pp. 456-461.

Lakeman, T.R., England, J.H. 2014. Facies and stratigraphical analyses of glacial and interglacial sediments at Morgan Bluffs, Banks Island, Canadian Arctic Archipelago. Boreas 43 (4), 895-913.

Lewkowicz, A.G. 1983. Erosion by overland flow. In Permafrost, Proceedings of the Fourth International Conference on Permafrost, 17-22 July, Fairbanks, Alaska. National Academy Press, Washington D.C., pp. 701-706.

Lewkowicz, A.G., Kokelj, S.V. 2002. Slope sediment yield in arid lowland continuous permafrost environments, Canadian Arctic Archipelago. Catena 46, 261-283.

Maher, W.J. 1968. Muskox bone of possible Wisconsin age from Banks Island, Northwest Territories. Arctic 21, 260-266.

Mackay, J.R. 1995. Ice wedges on hillslopes and landform evolution in the late Quaternary, western Arctic coast. Canadian Journal of Earth Sciences 32, 1093-1105.

Maxwell, J.B. 1980. The climate of the Canadian Arctic islands and adjacent waters. Climatological Studies, 30, Atmospheric Environment Service, Environment Canada, 531 pp.

Miall, A. 1979. Mesozoic and Tertiary geology of Banks Island, Arctic Canada. Geological Survey of Canada, Memoir 387, 234 pp.

Pissart, A. 1966. Le role géomorphologique du vent dans la region de Mould Bay (Île Prince Patrick, NWT, Canada). Zeitschrift fur Geomorphologie 10, 226-236.

Pissart, A. 1967a. Les pingos de l'Île Prince Patrick ( $\left.76^{\circ} \mathrm{N}-120^{\circ} \mathrm{W}\right)$. Geographical Bulletin 9, 189-217. 
Pissart, A. 1967b. Les modalities de l'écoulement de l'eau sur l'île Prince Patrick. Biuletyn Peryglacjany 16, 217-224.

Pissart, A. 1968. Les polygons de fente de gel de l'̂̂le Prince Patrick. Biuletyn Peryglacjany 17, 171-180.

Pissart, A., French, H.M. 1976. Pingo investigations, north-central Banks Island, Canadian Arctic. Canadian Journal of Earth Sciences 13, 937-946.

Pissart, A., French, H.M. 1977. The origins of pingos in regions of thick permafrost, Western Canadian Arctic. Questiones Geographicae 4, 149-160.

Pissart, A, Vincent, J.S., Edlund, S.A. 1977. Dépôts et phénomènes éoliens sur l'île de Banks, Territoires du Nord-Ouest, Canada. Canadian Journal of Earth Sciences 14, 2452-2480.

Porsild, A.E. 1955. The vascular plants of the Western Canadian Arctic Archipelago. Bulletin 135, National Museum of Canada, Ottawa, 226 pp.

Porsild, A.E. 1957. Illustrated flora of the Canadian Arctic Archipelago. Bulletin 146, National Museum of Canada, Ottawa, 209 pp.

Taylor, A.E., Judge, A.S. 1977. Canadian geothermal data collection - northern wells, 19761977. Geothermal Series No 10, Geothermal Service of Canada, Earth Physics Branch, Department of Energy, Mines and Resources, Ottawa, 194 pp.

Tedrow, J.C.F. 1966. Polar desert soils. Proceedings, Soil Science Society of America 30, 381-387.

Tedrow, J.C.F. 1974. Soils of the High Arctic landscapes. In T.L. Smiley, J.H. Zumberge (eds.), Polar deserts and modern man, University of Arizona Press, Tucson, pp. 63-69.

Tedrow, J.C.F., Douglas, L.A. 1964. Soil investigations on Banks Island. Soil Science 98, 53-65.

Tedrow, J.C.F., Bruggerman, P.F., Walton, G.F. 1968. Soils of Prince Patrick Island. Arctic Institute of North America, Research Paper 44, Washington, DC, 82 pp.

Thomas, D.S.G. 2011. Arid environments: their nature and extent. In D.S.G. Thomas (ed.), Arid zone geomorphology, 3rd edition, Blackwell, Oxford, pp. 3-16.

Thorsteinsson, R., Tozer, E.T. 1962. Banks, Victoria and Stefansson Islands, Arctic Archipelago. Geological Survey of Canada Memoir 330, 83 pp.

Tozer, E.T., Thorsteinsson, R. 1964. Western Queen Elizabeth islands, Arctic Archipelago. Geological Survey of Canada Memoir 332, 222 pp.

Vincent, J.S. 1982. The Quaternary history of Banks Island, NWT, Canada. Géographie physique et Quaternaire 36, 209-232.

Vincent, J.S. 1983. La géologie du Quaternaire et la géomorphologie de l'île de Banks, Arctique Canadien. Geological Survey of Canada Memoir 405, 118 pp. 